\title{
ENTREPRENEURIAL ATTITUDE AND STUDENT'S BUSINESS START- UP INTENTION: A PARTIAL LEAST SQUARE MODELING
}

\author{
Widayat ${ }^{*}$, Ni'matuzahroh $^{2}$ \\ ${ }^{1}$ Faculty of Economics and Business, University of Muhammadiyah Malang, Indonesia \\ ${ }^{2}$ Faculty of Psychology, University of Muhammadiyah Malang, Indonesia \\ *Corresponding author; Email: widayatumm@yahoo.com
}

\begin{abstract}
This article is designed to examine the role of the entrepreneurial spirit, education and in building an attitude about working as an entrepreneur, and his influence on the intention to start a business, to the students. Data were collected using a questionnaire has been prepared and maintained the validity and reliability. Questionnaires given to the respondent students were selected as samples at several universities in Malang, East Java, Indonesia. The collected data were analyzed by using Partial Least Square. The analysis showed entrepreneurial spirit and education contribute to the formation of entrepreneurial attitudes. Attitudes are formed encourage entrepreneurship intentions to start a business significantly.
\end{abstract}

Keywords: Start-up business, intention, spirit, entrepreneurial.

\section{Introduction}

Entrepreneurship is a well-known term in business and economics matter. Various literature reviews showed no uniform definition and it's a topic of controversy. That term can be learned at the macro or micro perspective. At the micro level entrepreneurship is defined as a competence of person. Wilhelmina and Tendai (2014) state that entrepreneurship as managerial skills possessed someone at institutions that combine resources to produce a good or services. Another view defines entrepreneurship as a resource refer to a process whereby a person take advantage of positive market opportunities by creating or establishing the new company and the person referred to as an entrepreneur, a managerial skill in taking advantage of opportunities to create goods or services, creative building a business, is contained in the values, spirit, power of innovation and risk-taking (Bula, 2012; Fitzsimmons \& Douglas, 2005a; Gelderen et al., 2008; Naudé, 2013; Okpara, 2007).

Studies of entrepreneurship at the micro level of individuals quite dynamic and become areas were phenomenal during the last decade (Tung, Ling, \& Ling 2011), because it's an important part of a country, its presence as a pillar of economic growth, as the engine of growth, stability, and to pave employment (Baumol, 2007; Harris, Gibson, \& Mick, 2009; Klucznik-Törö, 2014; Michael \& Shanan, 2009; Sorin-George, Ana-Maria, \& Paul, 2014; Wilhelmina \& Tendai, 2014). Based on ASEAN General Entrepreneurship report 2014/2015 showed that the entrepreneurship as a good career alternative. Community in that countrie, attitudes towards entrepreneurship is less in majority. According to the number of entrepreneur in many ASEAN countries and attitudes towards entrepreneurship between countries, raises interesting research questions regarding the attitudes towards entrepreneurship formation factors, and the consequences of attitude towards start-up a new business intention.

The study, which tried to portray attitudes towards entrepreneurship, and examines the variables that contribute to start-up a new business intention are not few in number. In theoretical studies, there are some basic theories used as a basis. Theory Reason Action (TRA) has been applied to explain the behavioral phenomena and has inspired the Theory of Planned Behavior (TPB). This theory specifically links between beliefs with attitudes. Based on the model of a person's will evaluate the attitude towards behavior is determined by the accessibility of confidence, which is a subjective probability that the behavior will produce definitive results. Expected outcome of something that is done a model of the expected value. This theory assumed that people behave under the control of desire (volitional control). Someone will behave in certain ways based on intentions, attitudes and beliefs about the performance behavior. Intention is assumed to be the best predictor of behavior and as a motivational factor affecting behavior. Intention would appear as a person's desires and efforts are being made to conduct. In turn, the intention is determined by attitude toward behavior and subjective norms related to behavior. The second aspect is a reflection of personal and environmental. Effect of intention and subjective norms to behavioral intention is varied and also depend on the personal 
situation. According to the theory, if someone was evaluated and recommended for positive behavior (attitude), and if they think someone else would suggest that he behaves (subjective norm), the result is a higher intention and they will be happy to be motivated to do something (well-behaved). So, the attitude and subjective norm have a high correlation. (Ajzen, 1991, 2011; Armitage \& Conner, 2001; Cameron, Ginsburg, Westhoff, \& Mendez, 2012; Holst \& Iversen, 2011; Rutherford \& DeVaney, 2004; Smith et al., 2007).

However, it is argued that the high indirectly correlation between attitudes and behaviors. Attitude and belief in the subjective norm correlated with behavior through preparedness (behavioral intention), and actual behavior is also caused by the environment. Theory of Planned Behavior (TPB), widely applied in explaining behavioral especially entrepreneurship, for examples Ariff, Bidin, Sharif, and Ahmad (2010), Fini, Grimaldi, Marzocchi, and Sobrero (2009), Sihombing (2011). Some researchers in the field of entrepreneurship play TPB theory, among others; (Holst \& Iversen, 2011; Kautonen, Van Gelderen, \& Fink, 2015). Limitations TRA and TPB to invite and challenge the researchers to develop a new theory (Gelderen, Kautonen, \& Fink, 2015). At the empirical level are not a few researchers are trying to replicate, modification or development of a model by adding the proposed relevant variables. However, from a number of studies that attempted to examine the relationship of the variables that are relevant to the context of entrepreneurship, showed that are still worthy follow up result.

Suppose, Aizzat, Noor, and Chew (2009) tried to approve a model using Structural Equation Modeling, they put affective variables and the perceived desirability, including role models, social identification and social norms on student's interest in entrepreneurship in Malaysia. The result shows that role models and social norms contribute to interest in entrepreneurship. While the results of the study Ahmed, Nawaz, Ahmad, Shauka, Usman, Wasim-ul-Rehman, \& Ahmed (2010) on students in Pakistan shows that interest to become entrepreneur as a result of the process of education, demography, and also one's personal characteristics. In studies Fitzsimmons and Douglas (2005b) found that the social aspects, such as attitudes towards income, freedom and additional income, risk and hard work contribute to determining the intentions and entrepreneurial behavior. In addition, it is also determined by cognitive biases, confidence or belief in entrepreneurship. While studies conducted $(\mathrm{Li}, 2007)$ on Chinese and Indian students at top universities in the Midwest United States, found that the intention of entrepreneurship is significantly influenced and supported by personal attractiveness and feasibility. While social norms it had no significant effect. Meanwhile, the findings Alsos, Isaksen, and Softing (2006) the students shows that there is a strong positive relationship between experience with entrepreneurship attitude.

Attitude in many existing research model often and always placed in the middle of the model. It meant that, left side of attitude their variables and also in the right one. Depart from the attitude on many models of existing research, there is two point of view; attitude as the dependent variable or as a predictor variable. While others researchers try to put a manner as variables that determine or as explanation variables. In the study tried to apply TPB, more directed to explain the influence or contribution of attitudes towards variable intentions. This means that many researchers tried to put a variable attitude as explanation behavioral intention and without looking at how attitudes are formed and what variables that will determine the formation or establishment attitude. Attitude as a variable most was left side in a model of behavior, whereas and ideally attitudes formed or formed by other variables. Departing from here, this article is designed to explain the variables forming attitudes towards entrepreneurship, and in turn affect entrepreneurial intentions that reflected by start-up business intention. The author tried to test the significance of the role of the variables that exist within the spirit of a person, and his attitude towards entrepreneurship in shaping attitudes towards entrepreneurship. In addition, test the contribution of attitudes towards entrepreneurship intention to initiate a structural model.

\section{Entrepreneurial Intention}

In classical or neoclassical theory there is no uniform definition of the entrepreneurship and the term has become a cross-disciplinary study of the social, economic, psychology and management. Entrepreneurship is a concept that can be seen from various disciplines, disciplinary or multi-dimensional mixed (Bula, 2012; Klucznik-Törö, 2014). Bull and Willard (1995) States that from being in the four studies; leads to the term entrepreneur as my head rather than on theory or concept that is in it, the psychological characteristics of a person, the key to success in managing the business and the factors influencing the success of attempted or start a business. Other source refer to entrepreneurship in some organizations which lead to the characteristic activities of the organization or someone in organization oriented to progress, growth, as capital to maximize profit (Douglas, 2013), the process of creating a company or a new organization 
(Khuong \& An, 2016) the ability to find opportunities (Krueger, Reilly, \& Carsrud, 2000), an organization's intellectual capital (Ngugi, 2014).

Starting a business (Start-up Business) one form of entrepreneurial activity is a concept raised in this paper. Before someone works they are exposed to a variety of career options, a worker in a business organization, whether public or private or create their own jobs is another problem for someone, especially their status is still a student. Intend to build an independent business is the initial formation of the business. An interesting problem is what factors influence whether or not strong intent for someone to start a business. One option that is still inviting various studies is to choose to start your own business. Various studies try to explain the theme, including Xiao and Fan (2012) which describes the contribution of entrepreneurial feasibility and desirability of the Entrepreneurial Intention with three sizes namely. Estimate the likelihood that you will start your own business in the foreseeable future it has crossed my mind to start a business of my own or with my partner, and do you plan to be self-employed in the foreseeable future? So far many researchers who use the concept of entrepreneurship intention among others, for examples Rantanena and Toikkob (2013), Remeikiene, Startiene, and Dumciuviene (2013), Douglas (2013), Gelderen et al., (2015) and Rengiah (2016).

\section{Attitude}

Attitude is one of the variables used in explaining human behavior, including in entrepreneurship research. Attitude is the tendency to respond to things in a way appropriate to the object either favorable or unfavorable attitude. In theory, the action of Fishbein and Ajzen and planned behavior of Ajzen (1991) as a prerequisite behavioral attitudes indirectly, through faith, to perform certain behaviors. An attitude toward a behavior is recognized as a positive or negative evaluation of the behavior of the relevant forms of belief regarding the proceeds to be received for such behavior. Where as subjective norm is a person's perception about significant reference. While the behavior control, received difficulties or easiness to behave, controls received directly affects behavior (Ajzen, 2011; Armitage \& Conner, 2001; Corner \& Armotage, 1998; Holst \& Iversen, 2011; Lekhanya, 2016).

Attitude subjective norm and external variable those affect of intention and ultimately determine that behavior, But that appears on someone's behavior is not always in tune with the attitudes toward physical objects or object behavior. Positive attitude towards the behavior of an object (ie. Entrepreneurship) is not always going establish positive behavior as well. This happens because there are control variables that become an obstacle or facilitate the formation of behavior. Variables that facilitate, encourage or difficult for the person to be known as behavioral control explains that the attitude structure consists of three components. Those components include cognitive, feeling (feeling component) and the tendency of action. Cognitive (cognition) is a general term in psychology which includes the mental processes that transforming the inputs into knowledge. These include mental processes of perception, thinking, language, memory and decision making. The study tried to portray, to measure attitudes to entrepreneurship are not few in number, including the Venesaar, Kolbre, and Piliste (2010), Segumpan and Zahari (2012), Rantanena and Toikkob (2013), Akanbi (2013).

\section{Education}

Education, especially entrepreneurship is the process of building or shaping attitudes or skill to learners. This process has been implemented in various medium to higher education institutions in Indonesia. Entrepreneurship education has an important role in establishing and further intention to foster new business in a country (Paço, Ferreira, Raposo, Rodrigues, \& Dinis, 2015a; Rengiah, 2016). Various studies indicate that the entrepreneurship education contribute to individual micro level and encourage the formation of the macro has a positive impact (Alhaji, 2015). In another study shows that education contributes a matching shape attitudes as at Fayolle and Gailly (2015), Hattab (2014), Remeikiene et al. (2013), Izedonmi and Okafor (2010), Wilhelmina and Tendai (2014), Byabashaija, Katono, and Isabalija (2010a), Oosterbeek, Van Praag, and Ijsselstein (2008) and also Bergmann, Hundt, and Sternberg (2016). Other studies show somewhat different things, that education is not always linearly positive impact on learners. In research of Alain, Benoît, and Narjisse (2006) found that the impact of education is a contingency. The results of the educational process will be positive in the specific conditions, depending on the background of each.

\section{Entrepreneurial Spirit}

Spirit of entrepreneurship is a personal trait or something of one's own strength is within oneself, (Miller, 2004). Spirit contribute to shaping the attitude and ultimately shape a person's behavior (Thyil \& Durden 2006). On the issue of entrepreneurship, the intention to build a business when reviewing the exis- 
ting theories such as TPB and TRA, one of which is determined by one's attitude about it. How attitudes are formed, is a question of deliberate studied in this paper. In this paper deliberately presented educational variables and spirit as the variables that contribute in shaping attitudes to entrepreneurship. Studies have attempted to portray the spirit as explanatory variables are not few in number, for example Galor and Michalopoulos (2009) stated that entrepreneurial spirit an important role in economic development, plays in the lives and well-being in the future for student Qosja and Druga (2015).

\section{Research Method}

This study aims to examine the building empirical models, which illustrate the interconnectedness of spirit, educational, attitudes and examined the contribution of attitudes toward intentions to start-up a business, based on data obtained from the students, from several universities in Malang, East Java, Indonesia. The research objective is achieved by using a quantitative approach to the design of the survey. Data were collected using questionnaires containing items indicator of each latent variable with a five-point Likert scale, from strongly agree to strongly disagree. The questionnaire used in advance and tested for validity and reliability. Testing the validity of using confirmatory factor analysis (CFAConfirmatory Factor Analysis), items that are valid and used for this study has a loading value of at least 0.5 and Construct Reliability at least 0.7 . Instruments granted to the respondent's selected sample is lacking accidental on their campus. The data has been analyzed using Partial Least Square (PLS) assisted SmartPLS data processing software.

\section{Results}

Of the 500 questionnaires were distributed to the respondents, was compiled and meet only about 401 . Completeness of the data is processed using SmartPLS, with as many as 180 cases bootstrapping method, derived models and statistical magnitudes as it exists in below. In table 1 is shown the value of composite reliability (CR) all latent variables greater than 0,700, Exposure indicates that all latent variables used in the model in this paper helps to build reliable, providing stable and consistent measurement. In Table 2 is shown loading a standardized value of each indicator forming latent variables. An indicator of items declared valid if the value of standardized loading of not less than 0,700. Latent variable attitudes towards entrepreneurship (ATTITUDE) prepared by the indicator with Att1 code-Att5. Latent Variables education composed of six indicators, namely Edu1-Edu6. Latent variables intention to start a business (business start-up) (INTEN TO START) composed by six indicators, namely Inten1-Inten5. Last latent variable is the spirit (SPIRIT) is composed of four items, namely Spirit1-spirit4 indicators, the overall value is above 0,700 loading propped up so that it can be said that the construction of the variable is composed by a valid indicator. Special on Education latent variables, loading coefficient value generated is not entirely above the critical number. Edu3 indicator value of 0.487955 loading only far below the 0.7 declared invalid so that the item is removed from the model, is not used as a variable constituent items Education.

Table 1

Composite Reliability

\begin{tabular}{lc}
\hline Latent variable & Composite Reliability \\
\hline ATTITUDE & 0.938054 \\
EDUCATION & 0.871296 \\
INTENTOSTART & 0.922947 \\
SPIRIT & 0.949632 \\
\hline
\end{tabular}

Table 2

Loading Factor (Standardized Weighted)

\begin{tabular}{|c|c|c|c|c|}
\hline $\begin{array}{l}\text { Item } \\
\text { Code }\end{array}$ & Attitude & Education & $\begin{array}{c}\text { Intent to } \\
\text { Start }\end{array}$ & Spirit \\
\hline Att1 & 0.790879 & & & \\
\hline Att2 & 0.845397 & & & \\
\hline Att3 & 0.874519 & & & \\
\hline Att4 & 0.926536 & & & \\
\hline Att5 & 0.893340 & & & \\
\hline EDU1 & & 0.702211 & & \\
\hline EDU2 & & 0.709520 & & \\
\hline EDU3 & & 0.487955 & & \\
\hline EDU4 & & 0.800000 & & \\
\hline EDU5 & & 0.828167 & & \\
\hline EDU6 & & 0.811332 & & \\
\hline Inten1 & & & 0.896326 & \\
\hline Inten2 & & & 0.880036 & \\
\hline Inten3 & & & 0.906959 & \\
\hline Inten 4 & & & 0.785289 & \\
\hline Inten5 & & & 0.719894 & \\
\hline Spirit1 & & & & 0.925827 \\
\hline Spirit2 & & & & 0.821644 \\
\hline Spirit3 & & & & 0.944944 \\
\hline Spirit4 & & & & 0.936197 \\
\hline
\end{tabular}




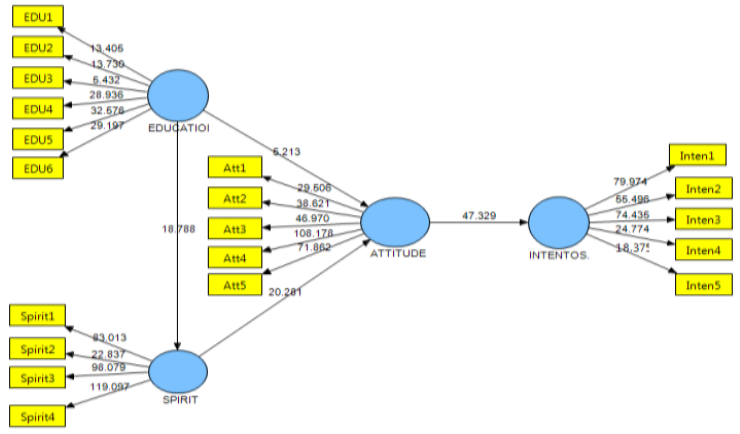

Figure 1.

Full Model with $T$-statistics.

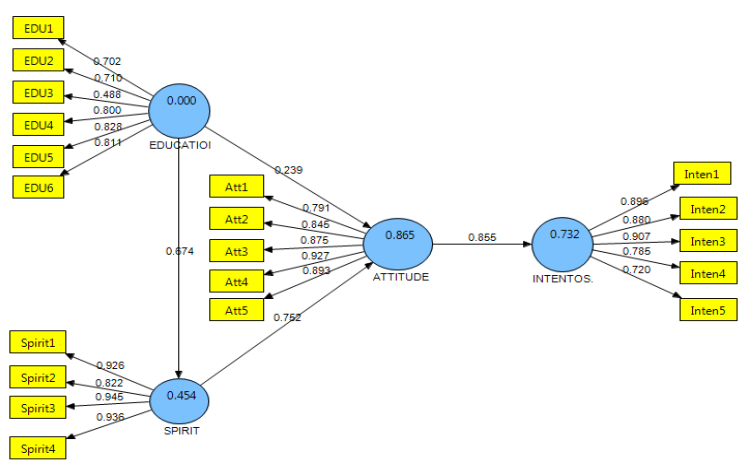

Figure 2.

Full Model with Standardized Weighted Coefficient.

Figures 1 and 2, indicated the measurement model for each latent variable and also the structural model that describes the influence of exogenous latent variables Education and the Spirit of the Attitude and the Influence of Attitude to Start-up Business Intention. The model illustrates how well (fit) the latent variable indicators compiled by the measuring, or how well the latent variable constituent indicators as a measure of the variable. While the structural models illustrates how powerful and significant latent variables influence one another that exists in the model. As has been described earlier in this paper, the author's emphasize the problems is a departure from existing variables in the model's center on attitudinal variables. In this paper, the authors examine the role of spirit possessed and received his education on attitudes about entrepreneurship formed on students.

The model in Figure 1 and 2 shows the $T$-statistic of educational pathways of 5.213, and the education-spirit of 18.788 and the spirit-attitude path 20.281. Value $T$-statistics as a whole is greater than the value of the $T$-critical (2.00). Likewise on path attitudes toward entrepreneurship intentions, the value of $T$-statistic of 47.329 is greater than the value of critical $T$. This indicates that the Education and the spirit of contributing to the formation of attitudes. Spirit who is on students is also supported by the education received. Attitude is a significant predictor of intention entrepreneurship. The model also known coefficient value or weight coefficient that describes the positive or negative direction and magnitude. Path of education-attitude have coefficient value of 0.239 . In this study, education was measured by five indicators measuring, relating to education obtained by study subjects. A positive value in the coefficient means that higher or intensive education received from the family, school and other environments the more positive student attitudes on entrepreneurship. On path line education-spirit (0.674) also is positive, it means that the education that the respondents will further evoke the spirit possessed. The path coefficients-spirit attitude is worth 0.762 . In the spirit of contributing to shaping attitudes turn; the higher the spirit possessed the more positive attitude towards entrepreneurship respondents, the path coefficient attitude-intention for 0.855 .

\section{Discussion}

Of modeling that has been done using software SmartPLS obtained the results as presented in Table 1 to Table 4 and Figure 1 and Figure 2 can be explained that construct latent variables namely, education, denoted EDUCATION, spirit possessed (SPIRIT), attitudes towards entrepreneurship (ATITUDE) and the intention to start a business (INTEN TO START) all have high enough reliability value greater than 0,700. Study of Fayolle and Gailly (2015) found that entrepreneurial education, specifically on the study known as the EEP (entrepreneurship education programs) proved to be a real effect on entrepreneurial attitudes and intentions. Additionally, (Paço, Ferreira, Raposo, Rodrigues, \& Dinis, 2015b) found that the education of entrepreneurship has important and influential role in shaping the intentions the case in studies conducted Hattab (2014) Alhaji (2015); Izedonmi and Okafor (2010); and also Mueller (2015).

This research conducted on students who never take or participate in education, training or on campus they are the subjects of entrepreneurship. Moreover, to those in the sample respondents were asked questions regarding their participation in entrepreneurship training program. Items to questions relating to the education variables are not only formal education but also non-formal in the family. From the model test shows that education does contribute to shape attitudes to entrepreneurship, this result supported by. However, attitudes are formed is not solely determined by aspects from outside but also a boost within oneself that is, the spirit. Spirit became burner, encouragement or even be a potential energy for a person. High and low spirit of a person, which is supported by 
an effective education will encourage the formation of a positive attitude. In this research found that entrepreneurial attitude influence Start-up business intention, and it's result supported by many researchers such as Veciana, Aponte, and Urbano (2005), Chen, Jing, and Sung (2012), Byabashaija, Katono, and Isabalija (2010b).

Entrepreneurship education does not always have the same impact on learners, because of the background of the person and spirit possessed, so education is a contingency. In certain circumstances, but a positive impact on other conditions were not so, as stated by Fayolle and Gailly (2015). A positive attitude does not guarantee encourages a person to intend to start a business, especially in the case of Indonesia due to factors motivation from the outside environment, debilitating, say program salary increase for civil servants. In theory, this condition is reasonable, if studied theory TPB (Ajzen, 1991; Armitage \& Conner, 2001; Corner \& Armotage, 1998). There are control variables that determine a person's behavior. Variable power control behavior, impact on the lack of intention misalignment influence on behavior. For example, government policies, the stimulus provided by the government can influence the attitudes and intentions of entrepreneurship.

\section{Conclusions and Implications}

This research leads to an empirical model that describes that entrepreneurial intention influenced by attitude toward entrepreneurship, and education affects the formation of positive attitudes about entrepreneurship and also able to evoke the spirit of entrepreneurship to students. Attitudes are formed, will encourage students intention to try to start a selfemployed or set up a business. From this research be presented a recommendation to the management or educational institutions in compiling or running the entrepreneurship education program to students. Education will not work or are not able to build attitude always effective because it depends on the background of the students, as well as and also the aspect of motivation comes from outside the student.

\section{References}

Ahmed, I., Nawaz, M. M., Ahmad, Z., Shauka, M. Z., Usman, A., Wasim-ul-Rehman, \& Ahmed, N. (2010). Determinants of students' entrepreneurial career intentions: Evidence from business graduates.

Aizzat, N. M., Noor, A. H., \& Chew, L. E. (2009). Examining a model of entrepreneurial intention among Malaysians using SEM procedure. Europen Journal of Scientific Research, 33(2), 10.

Ajzen, I. (1991). The theory of planned behavior. Organizational Behavior and Human Decision Processes, 50(2), 179-211. doi: 10.1016/07495978(91) $90020-\mathrm{t}$.

------. (2011). The theory of planned behavior: Reactions and reflections. Psychol Health, 26(9), 1113-1127. doi: 10.1080/08870446.2011.613995.

Akanbi, S. T. (2013). Familial factors, personality traits and self-efficacy as determinants of entrepreneurial intention among vocational based college of education students in Oyo State, Nigeria. An online journal of the African Educational Research Network, 13(2).

Alain, F., Benoît, G., \& Narjisse, L. C. (2006). Effect and counter-effect of entrepreneurship education and social context on student's intentions. $E$ STUDIOS DE E CONOMÍA A PLICADA, 24(2), 14.

Alhaji, A. (2015). Entrepreneurship education and its impact on self-employment intention and entrepreneurial self-efficacy. Humanities and Social Sciences, 3(1), 6. doi: 10.11648/j.hss.20150301. 17.

Alsos, G. A., Isaksen, E. J., \& Softing, E. (2006). Youth enterprise experience and business startup intentions. 14th Nordic Conference on Small Business Research. Stockholm, 11-13 May 2006.

Ariff, A. H. M., Bidin, Z., Sharif, Z., \& Ahmad, A. (2010). Predicting entrepreneurship intention among Malay university accounting students in Malaysia. UNITAR E-JOURNAL, 6(1).

Armitage, C. J. \& Conner, M. (2001). Efficacy of the theory of planned behaviour: A meta-analytic review. British Journal of Social Psychology, 40, 471-499.

Baumol, W. J. (2007). Entrepreneurship and innovation:Tthe (micro) theory of price and profit.

Bergmann, H., Hundt, C., \& Sternberg, R. (2016). What makes student entrepreneurs? On the relevance (and irrelevance) of the university and the regional context for student start-ups. Small Business Economics, 47(1), 53-76. doi: 10.1007/ s11187-016-9700-6.

Bula, H. O. (2012). Evolution and theories of entrepreneurship: A critical review on the Kenyan perspective. International Journal of Business and Commerce, 1(11).

Bull, I., \& Willard, G. E. (1995). Towards a theory of entrepreneurship. Journal of Business Venturing, $8(12)$.

Byabashaija, W., Katono, I., \& Isabalija, R. (2010a). The impact of college entrepreneurial education 
on entrepreneurial attitudes and intention to start a business in Uganda. Proceedings.

. (2010b). The impact of college entrepreneurial education on entrepreneurial attitudes and intention to start a business in Uganda. Entrepreneurship in Africa Conference.

Cameron, R., Ginsburg, H., Westhoff, M., \& Mendez, R. V. (2012). Ajzen's theory of planned behavior and social media use by college students. American Journal of Psychological Research, 8(1).

Chen, S. C., Jing, L. L., \& Sung, M. H. (2012). University students' personality traits and entrepreneurial intention: Using entrepreneurship and entrepreneurial attitude as mediating variable. International Journal of Economics and Management, 3(3), 76.

Corner, M. \& Armotage, C. (1998). Extending the theory of planned behavior; A review and avenues for futher research.

Douglas, E. J. (2013). Reconstructing entrepreneurial intentions to identify predisposition for growth. Journal of Business Venturing, 28, 27. doi: 10.1016/j.jbusvent.2012.07.005.

Fayolle, A. \& Gailly, B. (2015). The impact of entrepreneurship education on entrepreneurial attitudes and intention: Hysteresis and persistence. Journal of Small Business Management, 53(1), 18. doi: 10.1111/jsbm.12065.

Fini, R., Grimaldi, R., Marzocchi, G. L., \& Sobrero, M. (2009). The foundation of entrepreneurial intention.

Fitzsimmons, J. R. \& Douglas, E. J. (2005a). The impact of overconfidence on entrepreneurial intentions. In Proceedings AGSE Entrepreneurship Exchange. (2005b). Entrepreneurial attitudes and entrepreneurial intentions: A cross-cultural study of potential entrepreneurs in India, China, Thailand, and Australia. Babson-Kauffman Entrepreneurial Research Conference.

Galor, O. \& Michalopoulos, S. (2009). The evolution of entrepreneurial spirit and the process of development. Working Paper, 111.

Gelderen, M. V., Brand, M., Praag, M. V., Bodewes, W., Poutsma, E., \& Gils, A. V. (2008). Explaining entrepreneurial intentions by means of the theory of planned behaviour. doi: 10.1108/ 13620430810901688.

Gelderen, M. V., Kautonen, T., \& Fink, M. (2015). From entrepreneurial intentions to actions: Selfcontrol and action-related doubt, fear, and aversion.
Journal of Business Venturing, 30(28). doi: 10.1 016/j.jbusvent.2015.01.003.

Harris, M., Gibson, S., \& Mick, T. (2009). A connection between personality and entrepreneurial attitudes: Evidence from U.S. Business Students, 1.

Hattab, H. W. (2014). Impact of entrepreneurship education on entrepreneurial intentions of university students in Egypt. The Journal of Entrepreneurship, 23(1), 18. doi: 10.1177/097135571 3513346.

Holst, A. \& Iversen, J. M. (2011). An application of a revised theory of planned behavior: Predicting the intention to use personal care products without endocrine disrupting chemicals.

Izedonmi, P. F. \& Okafor, C. (2010). The effect of entrepreneurship education on students' entrepreneurial intentions. Global Journal of Management and Business Research, 10(6).

Kautonen, T., Van Gelderen, M., \& Fink, M. (2015). Robustness of the theory of planned behavior in predicting entrepreneurial intentions and actions. Entrepreneurship Theory and Practice, 39(3), 655-674. doi: 10.1111/etap.12056.

Khuong, M. N. \& An, N. H. (2016). The factors affecting entrepreneurial intention of the students of Vietnam national university: A mediation analysis of perception toward entrepreneurship. Journal of Economics, Business, and Management, 4(2), 7. doi: 10.7763/JOEBM.2016.V4. 375.

Klucznik-Törö, A. (2014). Results of the systematic literature review on entrepreneurship and its influencing factors. Forum Scientiae Oeconomia, 2(1).

Krueger, N. F., Reilly, M. D., \& Carsrud, A. L. (2000). Competing models of entrepreneurial intentions. Journal of Business Venturing, 15, 12.

Lekhanya, L. M. (2016). Critical analysis of entrepreneurial spirit, attitudes, and perceptions of young South Africans in KwaZulu-Natal province. Problems and Perspectives in Management, 14(3).

Li, W. (2007). Ethnic entrepreneurship: Studying Chinese and Indian students in the United States. Journal of Developmental Entrepreneurship, 12(4), 17. doi: 10.1142/S1084946707000769.

Michael, H. \& Shanan, G. (2009). A connection between personality and entrepreneurial attitude; Evidence from U.S business student.

Miller, R. L. (2004). Toward a model of spiritual entrepreneurship.

Mueller, S. (2015). Social entrepreneurship education: Student values, attitudes, and intentions. 
Naudé, W. (2013). Entrepreneurship and economic development: Theory, evidence and policy.

Ngugi, K. (2014). Intellectual capital theory of entrepreneurship. European Journal of Business Management, 2(1).

Okpara, F. O. (2007). The value of creativity and innovation in entrepreneurship. Journal of Asia Entrepreneurship and Sustainability, III(2).

Oosterbeek, H., Van Praag, M. C., \& Ijsselstein, A. (2008). The impact of entrepreneurship education on entrepreneurship competencies and intentions: An evaluation of the junior achievement student mini-company program.

Paço, A. D., Ferreira, J. M., Raposo, M., Rodrigues, R. G., \& Dinis, A. (2015a). Entrepreneurial intentions: Is education enough? International Entrepreneurship and Management Journal, 11(1), 22.

(2015b). Entrepreneurial intentions: Is education enough? International Entrepreneurship and Management Journal, 11(1), 8.

Qosja, E. \& Druga, E. (2015). Entrepreneurial spirit and factors affecting it: Case study based on the students of the European university of Tirana. Internationl Journal Of Social Science dan Education, 1(3).

Rantanena, T. \& Toikkob, T. (2013). Social values, societal entrepreneurship attitudes and entrepreneurial intention of young people in the Finnish welfare state. Poznań University of Economics Review, 13(1).

Remeikiene, R., Startiene, G., \& Dumciuviene, D. (2013). Explaining entrepreneurial intention of university students: The role of entrepreneurial education.

Rengiah, P. (2016). The effectiveness of entrepreneurship education in developing entrepreneurial intentions among Malaysian university students: A research findings on the structural equation modeling. European Journal of Business and Social Sciences, 5(2).

Rutherford, L. G. \& DeVaney, S. A. (2004). Utilizing the theory of planned behavior to understand convenience use of credit cards.
Segumpan, R. G. \& Zahari, J. S. A. (2012). Attitude towards entrepreneurship among Omani college students trained in business.

International Journal of Business and Behavioral Sciences, 2(4), 61-72.

Sihombing, S. O. (2011). Comparing entrepreneurship intention: A multigroup structural equation modeling approach. International Research Journal of Busines Studies, 5(1), 14.

Smith, J. R., Manstead, A. S. R., Terry, D. J., Louis, W. R., Kotterman, D., \& Wolfs, J. (2007). Interaction effects in the theory of planned behavior: The interplay of self-identity and past behavior. Journal of Applied Social Psychology, 37(11), 2726-2750.

Sorin-George, T., Ana-Maria, G., \& Paul, M. (2014). Economic development and entrepreneurship. Procedia Economics and Finance, 8, 7. doi: 10.1016/s2212-5671(14)00111-7.

Thyil, V. \& Durden, G. (2006). What exactly is entrepreneurial spirit? A conceptual framework and empirical evidence.

Tung, M., Ling, A. Y., \& Ling, D. M. (2011). Young adult responses to entrepreneurial intent. International Refereed reseaerch Journal, 2(3), 15.

Veciana, J. M., Aponte, M., \& Urbano, D. (2005). University students' attitudes towards entrepreneurship: A two countries comparison. International Entrepreneurship and Management Journal 1, 17.

Venesaar, U., Kolbre, E., \& Piliste, T. (2010). Students' attitudes and intentions toward entrepreneurship at Tallinn university of technology.

Wilhelmina, S. \& Tendai, C. (2014). Entrepreneurship, economic growth and entrepreneurship theories. Mediterranean Journal of Social Sciences. doi: 10.5901/mjss.2014.v5n14p160.

Xiao, L. \& Fan, M. (2012). Does social network always promote entrepreneurial intentions? part I: Theoretical model. 